\title{
Differences in the Defense Mechanism Technique modified (DMTm) between Depressive and Somatoform Disorder Patients
}

\author{
Lars Olsson \\ Department of Psychology, Lund University, Lund, Sweden \\ Email: larsolsson@sjobo.nu
}

Received 10 January 2015; revised 7 February 2015; accepted 20 February 2015

Copyright (C) 2015 by authors and Scientific Research Publishing Inc.

This work is licensed under the Creative Commons Attribution International License (CC BY).

http://creativecommons.org/licenses/by/4.0/

(c) (i) Open Access

\begin{abstract}
Differences in the Defense Mechanism Technique modified (DMTm), a percept-genetic tachistoscopic technique, between 56 patients with a main diagnosis of mild, moderate or severe unipolar depression and 42 with a main diagnosis of somatoform disorder were studied. As expected, the affect defenses of inhibition, introaggression and barrier isolation-all through their specified motive related to the depressive position of the affect positions model of the Andersson developmental and psychodynamic model of the mind-appeared more often with the depressive than the somatoform patients. Repression scored at the place of the threatening person in the DMTm pictures (Pp-repression) was more often found with the depressive patients, projected introaggression and no Pp-repression but repression scored at the place of the non-threatening person (H-repression) with the somatoform. In total less than four scorings of affect anxiety and affect defense, seen to indicate alexithymia, characterized the somatoform patients and those with mild depression. Denial through reversal II 3 and denial through reversal IV were common with the somatoform patients and those with severe depression. Denial was uncommon with mild depression. Denial, denial through reversal II 3 and denial through reversal IV increased the more severe the depression. The findings were interpreted according to the Andersson model.
\end{abstract}

\section{Keywords}

Defense Mechanism Technique modified (DMTm), Personality, Severity of Depression, Somatoform Disorder, Unipolar Depression 


\section{Introduction}

It is well established that symptoms that appear in patients with somatoform and anxiety disorders often also appear in patients with depressive disorders (Leiknes, Finset, Moum, \& Sandanger, 2007; Roca, Gili, GarciaGarcia, Salva, Vives, Garcia Campayo, \& Comas, 2009; Steinbrecher, Koerber, Frieser, \& Hiller, 2011). Since patients with these disorders in self-reports of personality seem to share many characteristics, some researchers find it unwarranted to regard them as separate disorders (Krueger \& Tackett, 2006). Klein, Kotov, and Bufferd (2011) recently addressed some methodological issues that are of importance when considering the relation between personality and psychopathology. They claimed, for example, that the heavy reliance on self-report questionnaires for measuring personality in connection with depressive disorders can be problematic because such estimates are influenced by, e.g., current mood state, limited insight, response styles and difficulty in distinguishing traits from stable environmental contexts. They were also concerned that the overlap between personality dimensions and psychopathology, e.g., between items describing neuroticism/negative emotionality and depression, could inflate the associations between them.

In an attempt to measure personality other than through questionnaire reports, the present author recently examined personality differences in the Spiral Aftereffect Technique (SAT) between patients with a main diagnosis of either unipolar depression or a somatoform disorder (Olsson, 2014). Measured over ten repeated aftereffect duration trials, a clear-cut difference between these two groups of patients was found. Successively longer aftereffect durations characterized the depressive patients, whereas successively shorter aftereffect durations ending in short or very short aftereffect durations characterized those with a somatoform disorder. The successively increasing aftereffect duration found with the depressive patients was seen to indicate a cognitive strategy that in the Andersson (1991; Andersson \& Ryhammar, 1998) developmental and psychodynamic model of the mind is linked to the depressive position of the affect positions model.

In the Andersson model, the three varieties of separation anxiety, affect anxiety and identity anxiety serve as main motives for three corresponding types of defenses in the order of denial, affect defenses (repression, projected introaggression, inhibition, introaggression, barrier isolation and affect isolation) and denial through reversal (four main types of identity defenses indicating failure to uphold distinctions connected with separateness, dissimilarity, gender and generation). There are also specified motives for these defenses that are distinguished from the main motives and obtained from three different psychoanalytic models: the reflex arc model or model of attachment (Freud, 1900; Bowlby, 1979) regarding the specified motive for denial, the affect positions model (Klein, 1935, 1940, 1946) regarding the specified motives for different types of affect defenses, and the model of self and selfobject (Kohut, 1971, 1977, 1984) regarding the specified motives for different forms of denial through reversal.

The present study is a further examination of differences between the same depressive and somatoform disorder patients as studied by Olsson (2014), now by use of a tachistoscopic technique utilizing successively longer short-time exposures of particular picture motifs, the Defense Mechanism Technique modified (DMTm). SAT and DMTm belong to a research tradition of studying personality through "perception as an event over time" (Smith, 1957), referred to as percept-genetic analysis (Kragh \& Smith, 1970; Rubino, 1987; Andersson, 1991). Findings with the SAT and the DMTm are interpreted within the theoretical framework of the Andersson model, and both techniques have proven to be of value in studying personality differences irrespective of whether the person examined is a psychiatric patient or not (for a summary of studies, see Andersson, 2004). DMTm has also turned out to be useful for the assessment of change due to psychotherapy (Andersson, Wilhelmsson, \& Tollin Olsson, 2007a, b).

Among previous clinical studies, DMTm has been used with schizophrenic patients (Lööf \& Svensson, 1993), depressive patients (Hallborg, 1997; Hallborg \& Andersson, 2002), drug abusers (Bergström, 1998; Montgomery, 2002; Aleman, 2006), and with patients characterized by somatization or psychosomatic disorders such as hypochondriacal complaints (Hallborg, Andersson, Nordgren, \& von Schéele, 1987), fibromyalgia (Jacobsson, 1989), ulcerative colitis (Andrée \& Marke, 1994) and eating disorders (Wilhelmsson \& Andersson, 2005; Wilhelmsson, 2012). A common characteristic of all these studies has been the ambition to differentiate between subgroups of patients within the same primary diagnosis, unlike the present study to differentiate by means of the DMTm between two different diagnostic groups.

Estimation of mild, moderate and severe depression is, according to DSM-IV (American Psychiatric Association, 2013) and DSM-5 (2013), regarded as having clinical utility, and is based on the number of criteria symptoms, the severity of the symptoms and the degree of functional impairment/distress. In cases of severe depres- 
sion, the presence of any psychotic symptoms is specified. The categories of mild, moderate and severe depression were employed by the physicians who made the diagnoses of the current depressive patients.

As reported in Olsson (2007), no difference between the present depressive and somatoform patients was found on the total score of the Beck Depression Inventory (BDI) (Beck \& Steer, 2001). There were differences, however, on three of five subscales defined by means of factor analysis, viz., on "depressed mood", "loss of weight and appetite" and "negative self-image", with the depressive patients scoring higher than the somatoform. No differences were found on the subscales of "somatic manifestations" and "negative social feelings". The BDI total score and the scores of the five subscales will here be examined in an effort to verify the relevance of the division of the depressive patients into severity groups.

The aim of the present study with DMTm was foremost to examine if one or more of the affect defenses of introaggression, inhibition and barrier isolation-all through their specified motive related to the depressive position of the affect positions model of the Andersson developmental and psychodynamic model of the mindwere more common among patients with a main diagnosis of unipolar depressive disorder than among patients with a main diagnosis of somatoform disorder. In addition to this hypothesis, any differences between the clinical groups-especially between the depressive and the somatoform patients, but also between the three depressive groups of severity — on other defenses and signs specified in the DMTm manual (Andersson, 2004) and in some later studies (Andersson \& Montgomery, 2005; Wilhelmsson \& Andersson, 2005; Andersson \& Sandström, 2010) will also be explored.

\section{Method}

The Declaration of Helsinki on human experimentation was followed.

\subsection{Participants}

The participants were 98 patients aged 18 - 70 yrs. $(M=43.3$, S.D. $=12.4), 59$ women and 39 men, in outpatient psychiatric care and primary care in a health district in the south of Sweden. Fifty-six patients, 37 women and 19 men (age range = 18 - 70 yrs.; $M=43.8$, S.D. = 13.4), had a main diagnosis of unipolar depression denoted, according to DSM-IV, as a major depressive disorder with either a single or recurrent episode and also classified as to the severity of the disorder. Fifteen had mild, 22 moderate and 19 severe depression. No patient had psychotic symptoms. The remaining 42 patients, 22 women and 20 men (age range $=20-68$ yrs.; $M=42.6$, S.D. $=$ 11.1), had as a main diagnosis one of the following somatoform DSM-IV disorders: somatization disorder $(n=$ $2)$, undifferentiated somatoform disorder $(n=31)$, somatoform pain disorder $(n=5)$ and hypochondriasis $(n=$ 4). Those having a diagnosis of pain disorder were all judged to have the disorder associated with psychological factors only. The DSM-IV somatoform disorders referred to as conversion disorder, body dysmorphic disorder and somatoform disorder NOS were not found in the present sample.

The participants were selected on the basis of their main diagnosis. The diagnoses were made by the patient's treating physician, one psychiatrist and two specialists in general medicine, all with extensive diagnostic experience, who asked them if they would agree to participate in the study. Only a few patients declined to participate after being asked. The patients were not allowed to use sedative drugs (e.g., benzodiazepines) two days prior to the DMTm testing. Otherwise, there was no restriction on the medication taken. The participants were paid a small sum of money for their participation.

\subsection{Beck Depression Inventory (BDI)}

The Beck Depression Inventory (BDI) is a self-report symptom inventory that was originally developed to examine changes due to treatment (Beck, Ward, Mendelson, Mock, \& Erbaugh, 1961). It is widely used for the assessment of depression (Tennen, Hall, \& Affleck, 1995) and is valid in different cultural settings (Bonicatto, Dew, \& Soria, 1998; Richter, Werner, Heerlein, Kraus, \& Sauer, 1998; Shek, 1991; Wang, Andrade, \& Gorenstein, 2005). The Swedish version of BDI (Beck \& Steer, 2001) was used in the present study (a later version, BDI II, was not available when the present data were collected).

BDI contains 21 items, each to be rated on a four-point scale of severity of symptoms (Beck, 1967; Beck, Weissman, Lester, \& Trexler, 1974). The total score ranges from 0 to 63 and is used as a measure of severity of depression. Details of the five BDI subscales of "depressed mood", "somatic manifestations", "loss of weight and appetite", "negative self-image" and "negative social feelings", all determined by means of a factor analysis 
of data from the present participants, can be found in Olsson (2007). How the BDI total score and the scores of the subscales were related to the three groups of depression severity is reported in Table 2.

\subsection{Defense Mechanism Technique modified (DMTm)}

In the DMTm (Andersson \& Bengtsson, 1985; Andersson \& Hallborg, 1986; Andersson, 2004), a sequel to the Defense Mechanism Test (Kragh, 1960, 1969; Andersson \& Weikert, 1974), two black-and-white picture motifs are shown tachistoscopically, each in a series of 20 exposures, the exposure times increasing successively from 5 milliseconds and then $8,10,13,17,23,30,40,55,70,95,125,165,220,290,380,500,660,870$, and 1150 milliseconds. An adult woman who is threatening is situated in the periphery of the first picture ("the threatening mother") and a threatening adult male in the second ("the threatening father"). In addition to the peripherally situated person (referred to as Pp), there is in each picture a centrally placed child (first picture) or young person (second picture) who is referred to as "hero/heroine" $(\mathrm{H}) . \mathrm{H}$ is always of the same gender as the testee. In front of $\mathrm{H}$ there is in each picture an object intended to represent a disguised sexual attribute (A). After each exposure, the testee reports verbally what he or she has seen and makes a simple drawing of it.

The report obtained in the DMTm is not an unmediated reflection of external reality. Rather, prior to correct recognition of the motifs, the material the individual produces is strongly colored by his or her very personal reconstruction and handling of the meaning of the themes shown in the pictures. The DMTm pictures are primarily aimed at arousing various forms of anxiety that can find expression either directly in the testee's report or indirectly as various signs of defense against anxiety. There are also some further signs.

The scoring of DMTm was made according to the manual (Andersson, 2004) together with the later defined signs of H-repression but no Pp-repression (Andersson \& Montgomery, 2005), of H sad (Wilhelmsson \& Andersson, 2005; Andersson \& Sandström, 2010) and in total less than four scorings of affect anxiety and affect defense (Wilhelmsson \& Andersson, 2005). As in the study of depressive patients by Hallborg (1997), denial through reversal II was divided into II 1 - 2 and II 3.

The scoring was performed independently by the present author and the originator of the DMTm manual, who did not know the diagnoses given. A few differences in the scoring were established before the data analysis. To be used as a variable, a sign had to occur in at least one of the two DMTm series and in at least 10 participants ( $10 \%$ of the present sample). The signs employed and how they were defined is given in Table 1 (for further details of the application and scoring of DMTm, see Andersson, 2004).

\subsection{Statistical Analysis}

To compare the results of the BDI obtained with the three depression severity groups, the Kruskal-Wallis one-way analysis of variance by ranks was used (Hollander, Wolfe, \& Chicken, 2014; Kruskal \& Wallis, 1952). When testing the relationship between the three depressive groups and DMTm signs ( $3 \times 2$ tables), the Pearson Chi-square Test was employed. The requirements of this test are that each observation is independent of the others, that no more than $20 \%$ of the expected counts are less than 5 , and that all individual counts are 1 or greater (Yates, Moore, \& McCabe, 1999; Weisburd \& Britt, 2007). The statistical significances of differences in DMTm signs between two groups $(2 \times 2$ tables $)$ were determined by means of the Fisher Exact Probability Test (two-tailed). Phi $(\varphi)$ was used as a measure of association (effect size) between the variables related to the hypothesis (Table 3).

\section{Results}

As can be seen in Table 2, there was a cogent agreement between the estimates of mild, moderate and severe depression made by the physicians and the depressive patients' self-report scores on the BDI, both with respect to the total score and the scores of the subscales.

The hypothesis that the depressive patients more often than those with a somatoform disorder should employ one or more of the defenses of inhibition, introaggression and barrier isolation was confirmed. In fact, each defense taken separately differentiated between the patient groups and one or more of them was also more common the greater the severity of the depression (Table 3).

There were further differences in the DMTm between the clinical groups (Table 4). Pp-repression was more common with the depressive patients, H-repression but no Pp-repression, projected introaggression, and denial through reversal II 3 with those with a somatoform disorder. The number of patients scored for denial, denial 
Table 1. Signs scored in the DMTm.

\begin{tabular}{|c|c|}
\hline Sign & Specified \\
\hline Affect anxiety & $\begin{array}{l}\text { Before Pp has become a person or a face, something dissolved, fragmented, or the like, is seen at that } \\
\text { location, or Pp is changed from a person or a face into something which is dissolved, diffuse, or the like, or } \\
\text { Pp is blotted out in a marked way without being lost completely. }\end{array}$ \\
\hline Identity anxiety & $\begin{array}{l}\mathrm{H} \text { is changed from a person or a face into something that is dissolved, diffuse, or the like, or } \mathrm{H} \text { is blotted out } \\
\text { markedly without being either in part or totally lost. }\end{array}$ \\
\hline H-repression & $\mathrm{H}$ is seen as a petrified, inanimate or disguised being, an animal or a specified object. \\
\hline Pp-repression & $\begin{array}{l}\text { Pp is seen as a petrified, inanimate or disguised being that is neither threatening nor unpleasant, as an animal } \\
\text { or as a specified object. }\end{array}$ \\
\hline A-repression & A is seen as a petrified, inanimate or disguised being or an animal. \\
\hline $\begin{array}{l}\text { Projected } \\
\text { introaggression }\end{array}$ & $\begin{array}{l}\text { Pp is seen as injured, tormented, dejected, sad, frightened, worried or exposed, or A is seen as something } \\
\text { which is damaged, broken, worthless, bad or threatening. }\end{array}$ \\
\hline Inhibition & $\begin{array}{l}\text { Pp is seen on at least five consecutive exposures as a petrified, inanimate or disguised being that is neither } \\
\text { threatening nor unpleasant, or as a specified object (Pp-repression not scored here), or Pp is seen on at least } \\
\text { five consecutive exposures as an object distinguished by its contour or as a framed, empty surface (barrier } \\
\text { isolation not scored here), or as a white or shining object or surface (affect isolation not scored here). }\end{array}$ \\
\hline Introaggression & $\begin{array}{l}\mathrm{H} \text { is seen as injured, wretched, in trouble, or the like, or as being critical toward the self or involved in a } \\
\text { situation of destructive character. }\end{array}$ \\
\hline Barrier isolation & $\begin{array}{l}\text { A barrier is added between } \mathrm{H} \text { and } \mathrm{Pp} \text { or } \mathrm{H} \text { and } \mathrm{Pp} \text { belonging to different realities, or Pp is seen as a framed, } \\
\text { empty surface or as an object distinguished by its contour. }\end{array}$ \\
\hline Affect isolation & $\begin{array}{l}\text { Pp is seen as a white or shining object or surface, or there is a total loss of the specified content in the } \\
\text { exposure preceding the loss. }\end{array}$ \\
\hline $\begin{array}{l}\text { In total less than four } \\
\text { scorings of affect } \\
\text { anxiety and affect } \\
\text { defense }\end{array}$ & $\begin{array}{l}\text { Signs of affect anxiety, H-repression, Pp-repression, A-repression, projected introaggression, inhibition, } \\
\text { introaggression, barrier isolation and affect isolation are scored less than four times in the } 40 \text { exposures ( } 20 \\
\text { from each of the two series). }\end{array}$ \\
\hline Denial & $\begin{array}{l}\text { Pp is missing or uninterpreted on at least seven consecutive exposures, starting with the first exposure, or Pp } \\
\text { is lacking or uninterpreted on at least two consecutive exposures after having been specified as something } \\
\text { other than a person or a face, or, when having been specified as a person or a face, Pp is lacking on at least } \\
\text { two consecutive exposures. }\end{array}$ \\
\hline $\begin{array}{l}\text { Denial through } \\
\text { reversal I }\end{array}$ & $\begin{array}{l}\mathrm{H} \text { is seen as doubled or more than two persons, or both } \mathrm{H} \text { and } \mathrm{Pp} \text { are children, } 15 \text { years old or younger, on at } \\
\text { least two exposures and } \mathrm{Pp} \text { is neither threatening nor unpleasant on these exposures. }\end{array}$ \\
\hline $\begin{array}{l}\text { Denial through } \\
\text { reversal II } 1 \text { - } 2\end{array}$ & $\begin{array}{l}\mathrm{H} \text { and } \mathrm{Pp} \text { are seen as having a positive relationship or Pp as being positive in character on at least two } \\
\text { exposures, or } \mathrm{H} \text { is seen as angry or threatening whereas Pp is seen as neither threatening nor unpleasant. }\end{array}$ \\
\hline $\begin{array}{l}\text { Denial through } \\
\text { reversal II } 3\end{array}$ & Pp is seen as neither threatening nor unpleasant on any of the exposures in a series. \\
\hline $\begin{array}{l}\text { Denial through } \\
\text { reversal III }\end{array}$ & $\begin{array}{l}\text { H's gender is changed from correct to incorrect, or is incorrect on at least eight consecutive exposures, but } \\
\text { not on all the exposures on which it is denoted, or H's gender is denoted but is not correct on any of the } \\
\text { exposures in a series. }\end{array}$ \\
\hline $\begin{array}{l}\text { Denial through } \\
\text { reversal IV }\end{array}$ & $\begin{array}{l}\text { Pp is seen as doubled or more than two persons or faces, or } \mathrm{H} \text { and Pp have exchanged location, or } \mathrm{H} \text { is seen } \\
\text { as a duplicate of Pp, or Pp's gender is changed from correct to incorrect but Pp is neither threatening nor } \\
\text { unpleasant when thus changed, or Pp is explicitly denoted as H's father in the first series or as H's mother in } \\
\text { the second series, and at the same time is neither threatening nor unpleasant, or Pp is a person younger than } \\
\mathrm{H} \text { and is neither threatening nor unpleasant, or } \mathrm{H} \text { is changed from a younger person to an older person, } 35 \\
\text { years of age or more, or } \mathrm{H} \text { is seen as an older person, } 35 \text { years of age or more, on at least } 12 \text { consecutive } \\
\text { exposures. }\end{array}$ \\
\hline Splitting of $\mathrm{H}$ & $\begin{array}{l}\mathrm{H} \text { is seen as two persons that are explicitly denoted as separated in distance, having different genders or } \\
\text { differing in other marked ways. }\end{array}$ \\
\hline $\begin{array}{l}\text { Disappearance of } \\
\mathrm{H} / \text { partial disappearance } \\
\text { of H/loss of meaning of } \\
\text { H/only Pp }\end{array}$ & $\begin{array}{l}\text { H disappears entirely after being specified as a person/H disappears partly and is only represented by some } \\
\text { body part, e.g., an arm, a leg or an upper part of the body without a head/H loses meaning or significance, } \\
\text { explicitly denoted after being a person/Pp is interpreted as something and neither } \mathrm{H} \text { nor A are denoted on the } \\
\text { same exposure. }\end{array}$ \\
\hline
\end{tabular}




\section{Continued}

\begin{tabular}{|c|c|c|c|c|c|}
\hline A child & \multicolumn{5}{|c|}{ A is denoted as a child. } \\
\hline Negation & \multicolumn{5}{|c|}{ Pp is explicitly denoted as non-threatening. } \\
\hline Disappearance of threat & \multicolumn{5}{|c|}{ Denotation of threat is missing for Pp on at least two consecutive exposures after an earlier indication. } \\
\hline H positive & \multicolumn{5}{|c|}{$\begin{array}{l}\mathrm{H} \text { is explicitly denoted as pleased, happy, satisfied or smiling and Pp is not denoted on the same exposure as } \\
\text { positive, angry, threatening or unpleasant. }\end{array}$} \\
\hline H sad & \multicolumn{5}{|c|}{$\mathrm{H}$ is explicitly denoted as sad or not happy (not scored in combination with introaggression). } \\
\hline \multicolumn{2}{|l|}{ BDI scale } & Depression group & Mean rank & $\chi^{2}(2 \mathrm{df})$ & $p$ \\
\hline \multicolumn{2}{|l|}{ Total score } & Mild & 15.27 & & \\
\hline & & Moderate & 25.66 & & \\
\hline & & Severe & 42.24 & 24.08 & .000 \\
\hline \multicolumn{2}{|l|}{ Depressed mood } & Mild & 18.83 & & \\
\hline & & Moderate & 29.27 & & \\
\hline & & Severe & 35.24 & 8.64 & .01 \\
\hline \multicolumn{2}{|c|}{ Somatic manifestations } & Mild & 17.33 & & \\
\hline & & Moderate & 24.66 & & \\
\hline & & Severe & 41.76 & 21.06 & .000 \\
\hline \multicolumn{2}{|c|}{ Loss of weight and appetite } & Mild & 21.97 & & \\
\hline & & Moderate & 26.23 & & \\
\hline & & Severe & 36.29 & 7.43 & .02 \\
\hline \multicolumn{2}{|c|}{ Negative self-image } & Mild & 20.40 & & \\
\hline & & Moderate & 24.89 & & \\
\hline & & Severe & 39.08 & 12.94 & .002 \\
\hline \multicolumn{2}{|c|}{ Negative social feelings } & Mild & 18.93 & & \\
\hline & & Moderate & 29.11 & & \\
\hline & & Severe & 35.34 & 8.85 & .01 \\
\hline
\end{tabular}

Table 3. Distributions (prevalence/no prevalence) in the clinical groups of signs in DMTm of affect defenses related to the depressive position of the affect positions model.

\begin{tabular}{|c|c|c|c|c|c|c|}
\hline $\begin{array}{l}\text { Sign in } \\
\text { DMTm }\end{array}$ & $\begin{array}{c}\text { Somatoform } \\
\text { disorder }\end{array}$ & $\begin{array}{c}\text { Mild } \\
\text { depression }\end{array}$ & $\begin{array}{c}\text { Moderate } \\
\text { depression }\end{array}$ & $\begin{array}{c}\text { Severe } \\
\text { depression }\end{array}$ & $\begin{array}{c}\chi^{2}(2 \mathrm{df}) \text { and } p \\
\text { depression groups }\end{array}$ & $\begin{array}{l}p \text { somatoform } \\
\text { disorder vs. } \\
\text { depression }\end{array}$ \\
\hline Inhibition & $1 / 41$ & $2 / 13$ & $4 / 18$ & $3 / 16$ & & .04 \\
\hline Introaggression & $4 / 38$ & $3 / 12$ & $7 / 15$ & $9 / 10$ & & .007 \\
\hline Barrier isolation & $5 / 37$ & $3 / 12$ & $11 / 11$ & $7 / 12$ & & .005 \\
\hline $\begin{array}{l}\text { One or more of } \\
\text { these signs }\end{array}$ & 9/33 & $6 / 9$ & $16 / 6$ & $16 / 3$ & 7.91 & $.00001(\varphi=.46)$ \\
\hline
\end{tabular}


Table 4. Distributions (prevalence/no prevalence) in the clinical groups of signs in the DMTm, other than those denoted in Table 3, that differentiated between the groups.

\begin{tabular}{|c|c|c|c|c|c|c|c|}
\hline Sign in DMTm & $\begin{array}{l}\text { Somatoform } \\
\text { disorder }\end{array}$ & $\begin{array}{c}\text { Mild } \\
\text { depression }\end{array}$ & $\begin{array}{l}\text { Moderate } \\
\text { depression }\end{array}$ & $\begin{array}{c}\text { Severe } \\
\text { depression }\end{array}$ & \multicolumn{2}{|c|}{$\begin{array}{c}\chi^{2}(2 \mathrm{df}) \text { and } p \\
\text { depression groups }\end{array}$} & $\begin{array}{l}p \text { somatoform } \\
\text { disorder vs. } \\
\text { depression }\end{array}$ \\
\hline Pp-repression & $10 / 32$ & $8 / 7$ & $17 / 5$ & $10 / 9$ & & & .0002 \\
\hline $\begin{array}{c}\text { H-repression } \\
\text { but no Pp-repression }\end{array}$ & $20 / 22$ & $4 / 11$ & $2 / 20$ & $4 / 15$ & & & .002 \\
\hline Projected introaggression & $10 / 32$ & $0 / 15$ & $1 / 21$ & $2 / 17$ & & & .01 \\
\hline $\begin{array}{l}\text { In total less than four } \\
\text { scorings of affect anxiety } \\
\text { and affect defense }\end{array}$ & $21 / 21$ & $9 / 6$ & $4 / 18$ & $4 / 15$ & 8.56 & .01 & \\
\hline Denial & $28 / 14$ & $2 / 13$ & $12 / 10$ & $13 / 6$ & 10.77 & .005 & \\
\hline Denial through reversal II 3 & $28 / 14$ & $2 / 13$ & $5 / 17$ & $12 / 7$ & 11.31 & .003 & .002 \\
\hline Denial through reversal IV & $23 / 19$ & $6 / 9$ & $8 / 14$ & $14 / 5$ & 6.50 & .04 & \\
\hline
\end{tabular}

through reversal II 3 and denial through reversal IV increased the more severe the depression. In all groups taken together, denial was uncommon with mild depression ( $2 / 13$ vs. $53 / 30, p=.0004)$. Denial through reversal II 3 was common with somatoform disorder and severe depression (40/21 vs. 7/30, $p=.00001)$, and so was denial through reversal IV (37/24 vs. 14/23, $p=.04)$. More patients with mild than with moderate or severe depression scored in total less than four scorings of affect anxiety and affect defense, and this sign characterized more often the patients with a somatoform disorder or mild depression than those with moderate or severe depression $(30 / 27$ vs. $8 / 33, \mathrm{p}=.001)$.

\section{Discussion}

In the DMTm, defenses appear as various verbal expressions in response to pictures with a threatening content. Two varieties of defenses are distinguished - the relational defenses of denial and denial through reversal and the affect defenses, the latter playing a prominent role in affect regulation. The affect defenses refer to different ways to ward off either the unconditionally or conditionally harmful or "evil" that is aroused by the threat in the pictures. In his developmental and psychodynamic model of the mind, Andersson (1991; Andersson \& Ryhammar, 1998) considers the unconditionally evil to have its origin in what the psychoanalyst Melanie Klein (1935, 1940, 1946) in her affect positions model refers to as the paranoid-schizoid position and it reappears in the manic-obsessional position; the conditionally evil is rooted in the depressive position.

The relational defenses display in different ways how the threatening interpersonal situation in the DMTm is handled. With the exception of denial through reversal II 3 (Pp seen as neither threatening nor unpleasant on any of the 20 exposures in a DMTm series), no differences were found for the relational defenses between the present main groups of depressive and somatoform patients, and there were no differences between them with respect to signs of anxiety and of signs in the DMTm that are usually given a literal interpretation (like splitting or disappearance of $\mathrm{H}$, etc.).

The primary findings of differences concerned affect defenses. In line with the hypothesis, one or more of the defenses of inhibition, introaggression and barrier isolation, all affect defenses that according to the Andersson model are seen to handle something conditionally evil linked to the depressive position, were in a very evident manner more often found with the depressive than the somatoform patients. This agrees with the finding in Olsson (2014) that the SAT strategy of successively increasing aftereffect durations, considered by Andersson (1983) to be a cognitive strategy that is rooted in the depressive position, was a distinctive feature of the present depressive patients. It should also be noticed that within the depressive group, one or more of the defenses of inhibition, introaggression and barrier isolation were more common the greater the severity of the depression.

Other affect defenses than those related to the depressive position that differentiated between the groups were projected introaggression, Pp-repression, and H-repression but no Pp-repression, all according to the Andersson model as being defenses against something unconditionally evil related to the paranoid-schizoid position of the 
affect positions model. The obvious "converse" of introaggression ( $\mathrm{H}$ seen as injured, wretched, in trouble, etc.) is projected introaggression (Pp seen as injured, tormented, etc., or A seen as something damaged, broken, etc.), and it seems therefore appropriate that the latter defense was more often found with the somatoform than the depressive patients.

In their study of patients with hypochondriacal complaints, Hallborg et al. (1987) emphasized that there is a basic difference between Pp-repression and H-repression, the latter indicating a kind of displacement of the evil to that part of the inner world that can be conceived of as the projected self. When H-repression appears without there being any scoring of Pp-repression, Andersson and Montgomery (2005) in their study of three different groups of drug addicts suggested that this DMTm characteristic might foremost be associated with "mental pain being experienced in that part of the self that the subject's own body represents" (p. 10). It is therefore quite interesting that $\mathrm{H}$-repression without the presence of Pp-repression in the present study was more often found with the somatoform than the depressive patients; and that Pp-repression, irrespective of whether it appeared together with H-repression or not, was typical of the depressive patients.

Andrée and Marke (1994) found in total less than four scorings of affect anxiety and affect defense more often with patients with distal ulcerative colitis (inflammation of a restricted part of the large intestine) than with patients with total ulcerative colitis (in which the entire large intestine is inflamed). The same DMTm characteristic was typical of one bulimic subgroup of the five subgroups, two anorexic and three bulimic, that Wilhelmsson and Andersson (2005) distinguished by means of cluster analysis. In the present study, this characteristic was more often found with the somatoform patients and those with mild depression than the patients with moderate and severe depression. Apparently, some of the former patients had difficulties in expressing and handling mental pain (affect anxiety) on a symbolic (verbal) level, which, as suggested by Andrée and Marke (1994), can be seen as an expression of alexithymia (Sifneos, 1973; Nemiah, 1996). For these patients an alternative should be an emotional acting out either through motor activity or within the body, the latter here indicated by their somatoform disorder. In some of the patients with mild depression, alexithymia might have led to their less evident depressive symptomatology.

The patients with a somatoform disorder were scored for denial through reversal II 3 more often than the depressive patients, though it was quite clear that this defense was frequently used not only by the somatoform patients but also by those with severe depression. Denial is often obtained together with denial through reversal II 3 in both clinical and non-clinical studies (Andersson \& Ryhammar, 1999), and Hallborg (1997) suggests in his study of depressive patients that the latter defense often might be seen as an "extension" of the former. This seems also to be true for the present study in that both denial and denial through reversal II 3 frequently appeared with the somatoform patients and that the occurrence of both these defenses increased with the severity of the depression.

According to the Andersson model, the relational defense of denial is ultimately a defense against abandonment at the same time as it is an attempt to keep the self intact when exposed to unpleasure evoked by an external threat. The finding that the relational defense of denial through reversal IV turned out to be more frequent the more severe the depression, together with the fact that this defense was frequently used not only by the patients with severe depression but also by the somatoform patients, is also of some interest. The specified motive of this defense of handling a threatened sense of self is the danger of losing the grandiose self, a motive in the Andersson model adopted from Heinz Kohut's (1971, 1977, 1984) model of self and selfobject.

As mentioned in the introduction, symptoms of depression and somatoform disorders often co-occur, and research using self-report inventories of personality has shown substantial similarities between patients suffering from depression, anxiety disorders or a somatoform disorder. The current study represents an alternative way of studying personality, and it has disclosed that the psychopathology of the present patients was related in the way predicted to their usage of the affect defenses of inhibition, introaggression and barrier isolation in the DMTm. There were also other defenses and signs in this percept-genetic technique that contributed to a further understanding of how the groups examined were different. DMTm thus seems to be a useful diagnostic tool together with the psychodynamic interpretations made according to the Andersson model when the purpose is to differentiate between patients with unipolar depression and somatoform disorder.

\section{Acknowledgements}

This study was supported by a grant from the County Council for Research and Development in the District of Kristianstad, Skåne, Sweden. 


\section{References}

Aleman, K. (2006). Psychoanalytic Conceptions of the Mind in Relation to Personality Disorders of Drug Abusers. Journal of Projective Psychology and Mental Health, 13, 125-138.

American Psychiatric Association (1994). Diagnostic and Statistical Manual of Mental Disorders (4th ed.). Washington DC: Author.

American Psychiatric Association (2013). Diagnostic and Statistical Manual of Mental Disorders (5th ed.). Washington DC: Author.

Andersson, A. L. (1983). Cognitive Growth, Psychoanalytic Conceptions of the Mind, Aftereffect Experience and Disavowal as a Defense against Percept-Genetic Threat. Archives of Psychology, 135, 103-114.

Andersson, A. L. (1991). Perceptgenes och personlighet [Percept-Genesis and Personality]. Lund: Lund University Press.

Andersson, A. L. (2004). Spiral Aftereffect Technique (SAT) och Defense Mechanism Technique modified (DMTm) [SAT and $D M T m$ ]. Lund: Department of Psychology, Lund University.

Andersson, A. L., \& Bengtsson, M. (1985). Percept-Genetic Defenses against Anxiety and a Threatened Sense of Self as Seen in Terms of the Spiral Aftereffect Technique. Scandinavian Journal of Psychology, 26, 123-139. http://dx.doi.org/10.1111/j.1467-9450.1985.tb01149.x

Andersson, A. L., \& Hallborg, A. (1986). Vägledning i perceptgenetisk försvarsdiagnostik med DMT och DMTm enligt Anderssons modell. Sju kliniska fall [A Guide to Percept-Genetic Diagnostics of Defenses with DMT and DMTm. Seven Clinical Cases]. Psykologi i tillämpning, Lunds universitet (Sweden), 4, No. 1.

Andersson, A. L., \& Montgomery, E. (2005). Drug of Choice as Related to Percept-Genetic Reconstruction of Personality in Terms of the Spiral Aftereffect Technique (SAT) and the Defense Mechanism Technique modified (DMTm). Lund Psychological Reports, 6, No. 3

Andersson, A. L., \& Ryhammar, L. (1998). Psychoanalytic Models of the Mind, Creative Functioning, and Percept-Genetic Reconstruction. Psychoanalysis and Contemporary Thought, 21, 359-382.

Andersson, A. L., \& Ryhammar, L. (1999). Personality of University Teachers According to the Defense Mechanism Technique modified (DMTm) as Related to their Assessment of their University as an Organizational Setting. Social Behavior and Personality, 27, 575-586. http://dx.doi.org/10.2224/sbp.1999.27.6.575

Andersson, A. L., \& Sandström, C. (2010). Characteristics of the Defense Mechanism Technique modified (DMTm) as Related to Age and Gender of Adolescent Inpatients at a Psychiatric Clinic. Lund Psychological Reports, 11, No. 1.

Andersson, A. L., \& Weikert, C. (1974). Adult Defensive Organization as Related to Adaptive Regulation of Spiral Aftereffect Duration. Social Behavior and Personality, 2, 56-75. http://dx.doi.org/10.2224/sbp.1974.2.1.56

Andersson, A. L., Wilhelmsson, M., \& Tollin Olsson, L. (2007a). Lack of Affect Defenses, Affect Isolation of an Inclusive Kind, or Affect Inhibition Were Uncommon in the Defense Mechanism Technique modified (DMTm) when Psychodynamic Therapy Was Recommended by the Clinical Staff. Lund Psychological Reports, 8, No. 4.

Andersson, A. L., Wilhelmsson, M., \& Tollin Olsson, L. (2007b). Enhanced Denial or the Emergence of Affect Isolation of an Inclusive Kind Were Uncommon in the Defense Mechanism Technique modified (DMTm) after Successful Psychodynamic Therapy. Lund Psychological Reports, 8, No. 5.

Andrée, S., \& Marke, K. (1994). Ulcerös kolit och affekthantering. En perceptgenetisk studie med SAT och DMTm i kombination med intervju [Ulcerative Colitis and Affect Regulation. A Percept-Genetic Study Using SAT and DMTm Combined with Interview]. Master of Science Thesis in Psychology, Department of Applied Psychology, Lund University, Sweden, 8, No. 19.

Beck, A. T. (1967). Depression: Clinical, Experimental and Technical Aspects. New York: Harper \& Row.

Beck, A. T., \& Steer, R. A. (2001). Beck Depression Inventory. Manual (Swedish Version). Stockholm: Psykologiförlaget.

Beck, A. T., Ward, C. H., Mendelson, M., Mock, J., \& Erbaugh, J. (1961). An Inventory for Measuring Depression. Archives of General Psychiatry, 4, 561-571. http://dx.doi.org/10.1001/archpsyc.1961.01710120031004

Beck, A. T., Weissman, M., Lester, D., \& Trexler, L. (1974). The Measure of Pessimism: The Hopelessness Scale. Journal of Consulting and Clinical Psychology, 42, 861-865. http://dx.doi.org/10.1037/h0037562

Bergström, M. (1998). Tre verkligheter. Kvinnor i olika stadier av narkotikamissbruk: En socialpsykologisk studie [Three Realities. Women in Different Stages of Drug Addiction: A Social Psychology Study]. Lund: Department of Applied Psychology, Lund University.

Bonicatto, S., Dew, A. M., \& Soria, J. J. (1998). Analysis of the Psychometric Properties of the Spanish Version of the Beck Depression Inventory in Argentina. Psychiatry Research, 79, 277-285. http://dx.doi.org/10.1016/S0165-1781(98)00047-X

Bowlby, J. (1979). The Making and Breaking of Affectional Bonds. London: Tavistock. 
Freud, S. (1900). The Interpretation of Dreams. Standard Edition, 4-5. London: Hogarth Press, 1953.

Hallborg, A. (1997). Symtomdimensioner vid depression i relation till tecken i DMTm [Relations between Symptom Dimensions in Depression and Signs in DMTm]. Psykologi i tillämpning, Lunds universitet (Sweden), 15, No. 4.

Hallborg, A., \& Andersson, A. L. (2002). Spiral Aftereffect Technique (SAT) och Defense Mechanism Technique modified (DMTm) efter tillfrisknande från depression i relation till symtomdimensioner och personlighetsrekonstruktion under det akuta skedet [Spiral Aftereffect Technique (SAT) and Defense Mechanism Technique modified (DMTm) after Recovery from Depression in Relation to Symptom Dimensions and Personality Reconstruction during the Acute Phase]. Psykologiska rapporter från Lund (Sweden), 3, No. 2.

Hallborg, A., Andersson, A. L., Nordgren, L., \& von Schéele, C. (1987). En perceptgenetisk och klinisk studie av patienter med hypokondriska besvär [A Percept-Genetic and Clinical Study of Patients with Hypochondriacal Complaints]. Psykologi i tillämpning, Lunds universitet (Sweden), 5, No. 2.

Hollander, M., Wolfe, D. A., \& Chicken, E. (2014). Nonparametric Statistical Methods. New York: Wiley.

Jacobsson, C. (1989). Fibromyalgi, smärta och försvar. En perceptgenetisk studie med SAT och DMTm [Fibromyalgia, Pain and Defense. A Percept-Genetic Study with SAT and DMTm]. Psykologi i tillämpning, Lunds universitet (Sweden), 7, No. 3.

Klein, D. N., Kotov, R., \& Bufferd, S. J. (2011). Personality and Depression: Explanatory Models and Review of the Evidence. Annual Review of Clinical Psychology, 7, 269-295. http://dx.doi.org/10.1146/annurev-clinpsy-032210-104540

Klein, M. (1935). A Contribution to the Psychogenesis of Manic-Depressive States. International Journal of Psychoanalysis, $16,145-174$.

Klein, M. (1940). Mourning and Its Relation to Manic-Depressive States. International Journal of Psychoanalysis, 21, 125-153.

Klein, M. (1946). Notes on Some Schizoid Mechanisms. International Journal of Psychoanalysis, 27, 99-110.

Kohut, H. (1971). The Analysis of the Self: A Systematic Approach to the Psychoanalytic Treatment of Narcissistic Personality Disorders. New York: International Universities Press.

Kohut, H. (1977). The Restoration of the Self. New York: International Universities Press.

Kohut, H. (1984). How Does Analysis Cure? Chicago, IL: University of Chicago Press. http://dx.doi.org/10.7208/chicago/9780226006147.001.0001

Kragh, U. (1960). The Defense Mechanism Test: A New Method for Diagnosis and Personnel Selection. Journal of Applied Psychology, 44, 303-309. http://dx.doi.org/10.1037/h0046004

Kragh, U. (1969). Manual till DMT-Defense Mechanism Test [Manual for the DMT-Defense Mechanism Test]. Stockholm: Skandinaviska Testförlaget.

Kragh, U., \& Smith, G. J. W. (Eds.) (1970). Percept-Genetic Analysis. Lund: Gleerup.

Krueger, R. F., \& Tackett, J. L. (Eds.) (2006). Personality and Psychopathology. New York: Guilford Press.

Kruskal, W. H., \& Wallis, W. A. (1952). Use of Ranks in One-Criterion Variance Analysis. Journal of the American Statistical Association, 47, 583-621. http://dx.doi.org/10.1080/01621459.1952.10483441

Leiknes, K. A., Finset, A., Moum, T., \& Sandanger, I. (2007). Current Somatoform Disorders in Norway: Prevalence, Risk Factors and Comorbidity with Anxiety, Depression and Musculoskeletal Disorders. Social Psychiatry and Psychiatric Epidemiology, 42, 698-710. http://dx.doi.org/10.1007/s00127-007-0218-8

Lööf, W., \& Svensson, M. (1993). Skillnader i DMTm mellan patienter med diagnoserna hebefreni, parafreni och icke regressiv schizofreni [Differences in DMTm between Patients with the Diagnoses of Hebephrenia, Paraphrenia and Non-Regressive Schizophrenia]. Psykologi i tillämpning, Lunds universitet (Sweden), 11, No. 1.

Montgomery, E. (2002). Drogval, kön och personlighet. En perceptgenetisk undersökning av narkomaner [Drug of Choice, Gender and Personality. A Percept-Genetic Investigation of Drug Addicts]. Lund: Department of Psychology, Lund University.

Nemiah, J. C. (1996). Alexithymia: Present, Past—and Future? Psychosomatic Medicine, 58, 217-218. http://dx.doi.org/10.1097/00006842-199605000-00004

Olsson, L. (2007). Discriminating Depressive Patients and Patients with Somatoform Disorders by Means of the Beck Depression Inventory (BDI). Lund Psychological Reports, 8, No. 3.

Olsson, L. (2014). The Spiral Aftereffect Technique (SAT) Can Differentiate between Depressive and Somatoform Disorder Patients. Perceptual and Motor Skills: Perception, 118, 522-532. http://dx.doi.org/10.2466/24.22.PMS.118k21w8

Richter, P., Werner, J., Heerlein, A., Kraus, A., \& Sauer, H. (1998). On the Validity of the Beck Depression Inventory. A Review. Psychopathology, 31, 160-168. http://dx.doi.org/10.1159/000066239

Roca, M., Gili, M., Garcia-Garcia, M., Salva, J., Vives, M., Garcia Campayo, J., \& Comas, A. (2009). Prevalence and Com- 
orbidity of Common Mental Disorders in Primary Care. Journal of Affective Disorders, 119, 52-58. http://dx.doi.org/10.1016/j.jad.2009.03.014

Rubino, I. A. (1987). La ricerca percettogenetica. Roma: Borla.

Shek, D. T. L. (1991). What Does the Chinese Version of the Beck Depression Inventory Measure in Chinese Students: General Psychopathology or Depression? Journal of Clinical Psychology, 47, 381-390. http://dx.doi.org/10.1002/1097-4679(199105)47:3<381::AID-JCLP2270470309>3.0.CO;2-D

Sifneos, P. E. (1973). The Prevalence of “Alexithymic” Characteristics in Psychosomatic Patients. Psychotherapy and Psychosomatics, 22, 255-262. http://dx.doi.org/10.1159/000286529

Smith, G. J. W. (1957). Visual Perception: An Event over Time. Psychological Review, 64, 306-313. http://dx.doi.org/10.1037/h0047487

Steinbrecher, N., Koerber, S., Frieser, D., \& Hiller, W. (2011). The Prevalence of Medically Unexplained Symptoms in Primary Care. Psychosomatics, 52, 263-271. http://dx.doi.org/10.1016/j.psym.2011.01.007

Tennen, H., Hall, J. A., \& Affleck, G. (1995). Depression Research Methodologies in the Journal of Personality and Social Psychology: A Review and Critique. Journal of Personality and Social Psychology, 68, 870-884. http://dx.doi.org/10.1037/0022-3514.68.5.870

Wang, Y. P., Andrade, L. H., \& Gorenstein, C. (2005). Validation of the Beck Depression Inventory for a PortugueseSpeaking Chinese Community in Brazil. Brazilian Journal of Medical and Biological Research, 38, 399-408. http://dx.doi.org/10.1590/S0100-879X2005000300011

Weisburd, D., \& Britt, C. (2007). Statistics in Criminal Justice. New York: Springer.

Wilhelmsson, M. (2012). Factorial Dimensions Obtained with the Eating Disorder Inventory (EDI) and the Karolinska Scales of Personality (KSP) in Women Having Anorexia Nervosa or Bulimia Nervosa as Related to Clinical and to Other Characteristics. Lund Psychological Reports, 12, No. 4.

Wilhelmsson, M., \& Andersson, A. L. (2005). An Attempt at Distinguishing Subgroups of Women with Anorexia Nervosa and Bulimia Nervosa by Means of the Defense Mechanism Technique modified (DMTm) and the Eating Disorder Inventory (EDI). Eating and Weight Disorders, 10, 175-186. http://dx.doi.org/10.1007/BF03327545

Yates, D., Moore, D., \& McCabe, G. (1999). The Practice of Statistics. New York: Freeman. 